\title{
Performing Injustice: Human Rights and Verbatim Theatre
}

\author{
Harry Derbyshire and Loveday Hodson ${ }^{*}$
}

\section{INTRODUCTION}

This interdisciplinary collaboration, located at the intersection between law and theatre, is a response to three recent theatrical interventions in the area of human rights which raise questions for scholars in each discipline. Although human rights are largely presented as a legal phenomenon, their articulation in dramatic form is one indication that rights transcend the formal legalistic framework within which they are commonly placed. The theatrical treatment of human rights allows for the dissemination of information, the arousal of compassion, and the raising of consciousness in a way that is particular to that form. In this article we consider three British productions: Guantánamo: 'Honor Bound to Defend Freedom' (2004); My Name is Rachel Corrie (2005), which dramatises occupation and protest in Palestine; and Called to Account (2007), which raises questions concerning the legality of the 2003 invasion of Iraq. All three plays deploy verbatim testimony in order to draw a particular kind of attention to human rights issues.

We begin with a discussion of recent legal scholarship that points to the limitations of human rights laws and their lack of connection to the human suffering they are intended to mitigate; we suggest, however, that such scholarship unnecessarily characterises human rights in formal legal terms that can never convey their full meaning. Ascribing meaning to human rights, we contend, is a cultural process that is not confined to corridors of power and courtrooms. We then move to a discussion of the three plays, establishing their theatrical context and the means by which they seek to intervene in the situations that they dramatise. We also consider the status of human rights laws as represented in these plays. Our final section explores the question of how far theatre can

Dr Harry Derbyshire, Lecturer in English and Drama, University of Greenwich, and Dr Loveday Hodson, Lecturer in Law, University of Leicester. With thanks to the editors of Law and Humanities and the anonymous referees of this article for their helpful feedback. 
have a practical impact as a socio-political force and, therefore, what it can do for human rights.

\section{THE ROLE OF LAW IN HUMAN RIGHTS DISCOURSE}

While the genesis of human rights ideology remains a matter of debate, it is widely recognised that human rights has been a significant force in national and international discourse since the end of World War II. ${ }^{1}$ The 1945 Charter of the United Nations and, subsequently, the Universal Declaration of Human Rights were part of a reordering of international relations that has legitimised international concern with human rights violations. ${ }^{2}$ Regionally, the Council of Europe, ${ }^{3}$ the African Union ${ }^{4}$ and the Organization of American States ${ }^{5}$ have all made the protection and promotion of human rights a central part of their purpose. Forsythe is far from alone when he describes the extent to which human rights discourse has come to impact upon the theory and practice of interstate relations as 'truly revolutionary'. ${ }^{6}$ In turn, human rights discourse has penetrated

1 For commentary on this point see, for example: R Smith, Textbook on International Human Rights, (2 edn Oxford University Press, 2005) 24; J Rehman, International Human Rights Law: A Practical Approach (Longman, Harlow 2002) 1; AH Robertson and JG Merrills, Human Rights in the World (4th edn Manchester University Press, Manchester 1996) 1; J Donnelly, International Human Rights (Westview Press, Boulder 1998 ) 4. For a survey of the pre-WWII human rights system, see HJ Steiner, P Alston and R Goodman, International Human Rights in Context: Law, Politics, Morals (3rd edn Oxford University Press, 2007) ch 2.

2 Article 1(3) of the Charter of the United Nations (adopted 26 June 1945, entered into force 24 October 1945) UKTS 1946 No 67, names 'promoting and encouraging respect for human rights and fundamental freedoms for all ...' as one of the essential purposes of the organisation. See also Articles 55 and 56.

3 Article 1 of the 1949 Statute of the Council of Europe (adopted 5 May 1949, entered into force 3 August 1949) 87 UNTS 103, reads:

(a) The aim of the Council of Europe is to achieve a greater unity between its members for the purpose of safeguarding and realising the ideals and principles which are their common heritage and facilitating their economic and social progress.

(b) This aim shall be pursued through the organs of the Council by discussion of questions of common concern and by agreements and common action in economic, social, cultural, scientific, legal and administrative matters and in the maintenance and further realisation of human rights and fundamental freedoms.

4 Article 3 of the Constitutive Act of the African Union (adopted 11 July 2000, entered into force 26 May 2001) OAU Doc CAB/LEG/23.15, provides: 'The objectives of the Union shall be to ... (h) promote and protect human and peoples' rights in accordance with the African Charter on Human and Peoples' Rights and other relevant human rights instruments ...'

5 Article 3(1) of the 1948 Charter of the Organization of American States (adopted 30 April 1948, entered into force 13 December 1951: several subsequent amendments) 119 UNTS 3, provides that: 'The American States proclaim the fundamental rights of the individual without distinction as to race, nationality, creed, or sex.' Chapter XV of that treaty provides for an Inter-American Commission on Human Rights (a body that was initially established by Resolution VII of the Fifth Meeting of Consultation of Ministers of Foreign Affairs, Santiago, 12-18 August 1959).

6 DP Forsythe, Human Rights in International Relations (Cambridge University Press, 2000) 4. 
national systems, with most modern constitutions declaring respect for human rights, ${ }^{7}$ and national and trans-national actors commonly seizing upon human rights arguments in support of their political claims. ${ }^{8}$ In fact, 'rights talk' has become widespread in modern times. Henry J Steiner and Philip Alston echo the sentiments of many when they observe that the human rights ideal 'has become a part of modern consciousness, a lens through which to see the world, a universal discourse, a potent rhetoric and aspiration'. ${ }^{9}$

If human rights ideology has penetrated cultural and political mainstreams, law has been both the most prominent means by which human rights have been pursued and the primary discourse through which human rights have been discussed. In the rush of enthusiasm for human rights that followed World War II, the declaration of a variety of formal laws designed to protect human rights was seized upon as a means of giving concrete expression to an otherwise abstract ideology. A plethora of international and regional laws giving voice to general and specific human rights concerns have been created, ${ }^{10}$ which have been mirrored in numerous regional human rights instruments. ${ }^{11}$

7 Some well-known examples are the Canadian Charter of Rights and Freedoms (which forms the first part of the Constitution Act 1982), the Constitution of the Republic of South Africa of 1996, and the Republic of Iraq Constitution of 2005. Steiner and Alston have noted that 'Since the end of the Cold War new constitutions, including bills of rights, have been adopted in a great many countries. In Central and Eastern Europe alone, there have been more than 25 new or revised constitutions in that time. Developments in Africa have been characterized as a prolonged fit of "constitutional fever"; a 1998 compilation included 20 constitutions published in French since 1990.' (HJ Steiner and P Alston, International Human Rights in Context: Law, Politics, Morals (2nd edn Oxford University Press, 2000) 990).

8 See, for example: ME Keck and K Sikkink, Activists Beyond Borders: Advocacy Networks in International Politics (Cornell University Press, Ithaca and London 1998); P Willetts (ed), "The Conscience of the World": The Influence of Non-Governmental Organisations in the UN System (Hurst \& Co, London 1996).

9 Steiner and Alston (n 7) v.

10 Internationally, the major human rights treaties are: the 1996 International Covenant on Civil and Political Rights (adopted 16 December 1966, entered into force 23 March 1976) 999 UNTS 171; the 1996 International Covenant on Economic, Social and Cultural Rights (adopted 16 December 1966, entered into force 3 January 1976) 993 UNTS 3; the 1966 Convention on the Elimination of All Forms of Racial Discrimination (adopted 21 December 1965, entered into force 4 January 1969) 660 UNTS 195; the 1979 Convention on the Elimination of All Forms of Discrimination against Women (adopted 18 December 1979, entered into force 3 September 1981) 1249 UNTS 513; the 1984 Convention against Torture and Other Cruel, Inhuman or Degrading Treatment or Punishment (adopted 10 December 1984, entered into force 26 June 1987) 1465 UNTS 85; the 1989 United Nations Convention on the Rights of the Child (adopted 20 November 1989, entered into force 2 September 1990) 1577 UNTS 3; the 1990 International Convention on the Protection of the Rights of All Migrant Workers and Members of Their Families (adopted 18 December 1990, entered into force 1 July 2003) 2220 UNTS 93; the 2006 International Convention for the Protection of all Persons from Enforced Disappearances (adopted 20 December 2006, not yet entered into force) GA Res A/61/177 (2006), reprinted in (2007) 14 International Human Rights Reports 582; and the 2006 Convention on the Rights of Persons with Disabilities (adopted 13 December 2006, entered into force 3 May 2008) GA Res A/61/611, (2006) 46 International Legal Materials 443.

11 Regionally, one might refer, amongst others, to the 1950 European Convention for the Protection of Human Rights and Fundamental Freedoms (adopted 4 November 1950, entered into force 3 September 1953) 213 UNTS 222; the 1969 American Convention on Human Rights (adopted 21 November 1969, entered into force 18 July 1978) 1144 UNTS 123; and the 1981 African Charter on Human and Peoples' Rights (adopted 27 June 1981, entered into force 21 October 1986) 1520 UNTS 217. 
Several of those instruments establish relatively sophisticated monitoring mechanisms to secure compliance with their terms. As already noted, human rights also make an appearance in most modern constitutions, securing them the highest possible legal protection. Furthermore, the vast majority of human rights scholarship to date has been undertaken by legal academics: as Michael Freeman has noted, 'human-rights talk is ubiquitous, but human-rights study is still predominantly legalistic.' ${ }^{12}$

The ubiquity of law in the human rights movement is perhaps understandable. Formal laws are both programmatic and enforceable: they can set normative standards and prescribe boundaries and limits to States' behaviour. Prescribed in formal legal terms, human rights cannot be considered mere rewards distributed by benevolent governments. Jack Donnelly has argued that those capacities accord law a unique importance in human rights discourse: ${ }^{13}$

The law, largely independent of its substance, has a certain authority and normative force. Even where (international and even national) legal norms diverge sharply from national political practice, the critical leverage provided by legal authority can be of real significance, especially in the long run.

Accordingly, those with an interest in human rights have tended to put considerable faith in formal legal solutions to human suffering and inequality, emphasising law's juridical, performative power. Defining and understanding the human rights project in purely positivist terms, however, has the effect of reducing human rights to a set of prescribed rules, which has allowed some commentators to see the inevitably limited effectiveness of state-declared laws as a tool to address injustice and challenge engrained power-structures as proof of the overall failure of human rights.

It is easy to see how this has happened. All too often human rights laws have been unable to live up to expectations that they will make a positive difference. Human rights treaties are born out of compromises made by state representatives in politicised environments, and it is States themselves that bear the burden of enforcing human rights treaties. ${ }^{14}$ The ability of formal laws to protect individual rights, hampered as they often are by weak enforcement mechanisms, falters, often to dramatic effect, when they collide with the other political imperatives-a problem that has been particularly apparent in a climate dominated by the threat of terrorism. From a liberal perspective, the obvious remedy is reform, strengthening law's power to operate as intended. However, a powerful argument has emerged from the left which presents human rights themselves as having

12 M Freeman, 'Putting Law in its Place: An Interdisciplinary Evaluation of National Amnesty Laws' in S Meckled-García and B Çali (eds), The Legalization of Human Rights: Multidisciplinary Perspectives on Human Rights and Human Rights Law (Routledge, Abingdon 2006) 52-53.

13 J Donnelly, 'The Virtues of Legalization' in Meckled-García and Çali (n 12) 74.

14 R Kapur makes this point when she argues that 'the gap between formal rights and the actual status of disadvantaged groups has not decreased as a result of the legalization process' (R Kapur, 'Revisioning the Role of Law in Women's Human Rights Struggles' in Meckled-García and Çali (n 12) 101). 
served to institutionalise and legitimise the power of States: from this viewpoint, the very act of describing formal legal limits to States' power serves to validate the exercise of that power. In The End of Human Rights, Costas Douzinas argues that declarations such as the revolutionary constitutional documents of the late eighteenth century 'proclaim the universality of right but their immediate effect is to establish the boundless power of the state and its law.'. ${ }^{15}$ Douzinas's critique seriously challenges the utility of human rights as a tool with which to confront the misuse of power. The potential benefits of law are cast aside in despair: the 'end of human rights' has been reached.

Douzinas's comments are part of a wider critique of rights that has had a powerful impact on recent debate, making this a bewildering time for those accustomed to expressing their concern for inequality and human suffering through the language of human rights. The basis of this sceptical position, however, is an excessive emphasis on the formal legal aspect of the human rights project and, therefore, we would argue, those who have declared its failure have done so on grounds that concede much to formal positivism. ${ }^{16}$ It is indeed important to acknowledge the limited effectiveness of law as a set of formal rules, but it must also be recognised that law operates both as a performative force and as part of a wider discursive network in which notions such as justice and human rights, which have meanings that extend beyond formal law, may be considered and articulated. It is only as part of such a network that human rights law may be appropriately connected to a wider understanding of human rights, not only as legal expectations but as expressions of empathy with and compassion for the suffering of the powerless.

The problem, then, is not to do with human rights as such but with an excessively formal or positivist understanding of them, and so it is neither necessary nor helpful to reject human rights and to declare their failure. The need is for those with an interest in human rights to understand them more imaginatively and more empathetically. Patricia Williams, viewing the situation from the point of view of those who are dispossessed, argues that the problem with rights is not that the discourse is itself constricting but that it exists in a constricted referential universe': ${ }^{17}$

'Rights' feels new in the mouths of most black people. It is still deliciously empowering to say. It is the magic wand of visibility and invisibility, of inclusion and exclusion, of power and no power. The concept of rights, both positive and negative, is the marker of our citizenship, our relation to others.

Correspondingly, Martha Minow asserts that communities are strengthened by sharing a commitment to restrain power, 'so that even the powerless can appeal to those words.' ${ }^{18}$

15 C Douzinas, The End of Human Rights (Hart Publishing, Oxford 2000) 101.

16 For a collection of essays on this issue see Meckled-García and Çali (n 12).

17 PJ Williams, The Alchemy of Race and Rights (Virago Press, London 1993) 159, 164.

18 M Minow, 'Interpreting Rights: an Essay for Robert Cover' (1987) 96 Yale Law Journal 1860, 1910. 
Human rights language, recognised as it is by those in positions of authority, can still act a 'brace against power'. ${ }^{19}$

If meaning is often given to human rights norms, as Minow argues, outside of formal legal frameworks, ${ }^{20}$ then human rights scholars, including legal scholars, need to expand the frames of reference within which they work to include the experiences of the dispossessed. Their aim, as Upendra Baxi has suggested, might be to connect the concept of human rights with an understanding of human suffering: 'the statist human rights discourse in its enunciations of human rights does not relate to languages of human pain and social suffering. ${ }^{21}$ Conor Gearty has argued a similar point, but has suggested that compassion might be a more suitable foundation for human rights than suffering, in that implicit in the latter is an emphasis 'on action as well as a caring state of mind'. ${ }^{22}$ As Kapur has argued, 'human rights when conceived primarily as a formal legal project, is not a realm of transformative political possibilities, ${ }^{23}$ but it may well be that an alternative conception of human rights allows them greater agency. The connection between human rights and human suffering for which Baxi and others have called may be facilitated by attending less to formal law and more to the social and cultural activity that gives law meaning.

In this paper we start from the position that the creation of legal meaning is a process shaped by cultural dialogues, and indeed that social and cultural activity is required to give law meaning. ${ }^{24}$ Human rights, we propose, is best understood as a space where law interacts with other kinds of cultural and social activity in order to advance the claims of those whose humanity has not been fully acknowledged. ${ }^{25}$ Viewed in this light human rights can be envisaged as a discursive space in which injustice and suffering are described and claims to redress imbalances of power are made, not necessarily through reference to formally announced laws. This vision of human rights allows that law's authority and language of judgement has a utility — the disempowered can find law's assertive discourse useful in framing and enforcing their rights claims-but does not overestimate the capacity of formal laws to engender change. Human rights, in this model, can play a

19 Ibid, 1897.

20 Ibid, 1861-2.

21 U Baxi, The Future of Human Rights (Oxford University Press, New Delhi 2002) 17.

22 C Gearty, Can Human Rights Survive? (Cambridge University Press, 2006) 46.

23 Kapur (n 14) 112

24 See RM Cover, 'Nomos and Narrative' (1983-4) 97 Harvard Law Review 4; CA Reich, 'Towards the Humanistic Study of Law' (1964-5) 74 Yale Law Journal 1402. See also J Boyd White, Heracles' Bow: Essays on the Rhetoric and Poetics of the Law (University of Wisconsin Press, Madison 1985) and When Words Lose their Meaning: Constitutions and Reconstitutions of Language, Character, and Community (University of Chicago Press, Chicago 1984).

25 For an attempt to understand international law as a discourse of popular resistance see B Rajagopal, International Law from Below: Development, Social Movements and Third World Resistance (Cambridge University Press, 2003). 
central part in an ongoing process of social reordering, a process in which law engages alongside other disciplines.

Central to the advantages of viewing human rights laws in this way is that it opens them up to the free play of imagination. Unconstrained by narrow formal positivism, we are free to imagine what human rights 'ought to' or 'might' look like. Marginalised people may benefit from this activity, which can facilitate the ongoing disruption and reimagining of human rights and allow the narratives of those silenced by formal laws to be incorporated into human rights discourse. ${ }^{26}$ Jeanne Gaakeer describes this approach to law as one 'that can provide openness against the dominance of any world view, allowing for a polyphony of voices.'27 Such cultural activity may not only point to what is wrong with officially declared laws, but can generate radical alternatives to them and operate as a 'potential restraint on arbitrary power and violence'. ${ }^{28}$ The process of developing shared understandings of legal meaning through conversations is presented by Gaakeer as a constructive one because 'social intercourse forces us to recognize the needs of others'. ${ }^{29}$ While this approach to law does not enable one to find the closure that formal legal texts appear to promise, embracing the apparent instability of non-scientific understandings of law allows us to move closer to a humane conception of human rights.

For this opportunity to be acted upon, however, means recognising the extrinsic link between law and the societies and cultures within which it operates. Law is a matter of concern not merely among lawyers but within the public sphere, a deliberative space in which ideas and arguments of common concern can be assessed by a critical public. In Habermas's conception 'the products of culture' are an important means by which such debate is generated, and any consensus that is reached in the public sphere will have an impact upon the political, and therefore the legal, realm. ${ }^{30}$ Theatrical performances of human rights issues and legal practice place ideas and arguments before audiences, prompting and informing debate in a way that exemplifies this process.

26 See, for example: C Heilbrun and J Resnik, 'Convergences: Law, Literature and Feminism', (1989-90) 99 Yale Law Journal 1913; Williams (n 17).

27 J Gaakeer, Hope Springs Eternal: An Introduction to the Work of James Boyd White (Amsterdam University Press, Amsterdam 1998) 165.

28 Cover (n 24) 68.

29 Gaakeer (n 27) 34. See also Boyd White, 1984 (n 24) 273, who says the following:

To conceive of the law as a rhetorical and social system, a way in which we use an inherited language to talk to each other and to maintain a community, suggests in a new way that the heart of the law is what we always knew it was: the open hearing in which one point of view, one construction of language and reality, is tested against another. The multiplicity of readings that the law permits is not its weakness but its strength, for it is this that makes room for different voices and gives a purchase by which culture may be modified in response to the demands of circumstance. It is a method at once for recognizing others, for acknowledging ignorance, and for achieving cultural change.

30 J Habermas, The Structural Transformation of the Public Sphere, trans Thomas Burger (Polity, Cambridge 1992) 29. For a discussion of the relationship between the literary public sphere and public sphere in the political realm, see pp 51-56 of that text. 
James Boyd White has written, 'Law always operates through speakers located in particular times and places speaking to actual audiences about real people'. ${ }^{31}$ The emphasis on positive law in legal education, the inclination amongst lawyers to impose order and deny the ultimate ambiguity of meaning, has led many lawyers to think in formal terms rather than to explore the transformative potential of law in practical situations. The theatre offers a way of imaginatively exploring the possibilities offered by human rights discourse, making it potentially more successful than law at disrupting dominant discourses in human rights. Moreover, the formality and practicality that tend to characterise legal discourse can be balanced by the imaginative, emotional response to the experience of others that is made possible by its articulation within a theatrical context, allowing the required connection between human rights and human suffering and leading to increased pressure for change. We turn now to consider these propositions in the light of three recent theatrical productions that draw attention to human rights issues.

\section{GUANTÁNAMO, MY NAME IS RACHEL CORRIE, AND CALLED TO ACCOUNT}

Since Ancient Greece, theatre has acted as a forum in which political and moral issues can be debated and explored, lacking the immediate practical impact of law but surpassing it in range and depth. ${ }^{32}$ Verbatim theatre, a mode of theatrical intervention developed since the 1990s, is of particular interest here. Three examples of verbatim theatre in performance will be described in this section, each representing an interesting variation on the model; having outlined their differences of approach but essentially similar intentions, we will consider how far they articulate and address aspects of human rights which are beyond the scope of the law, and what status law is accorded within them. In a separate and final section, we will explore the question of what practical efficacy such drama might have in the arena of human rights. The first play that we will look at is Guantánamo: 'Honor Bound to Defend Freedom' (Tricycle, 2004); the second is My Name is Rachel Corrie (Royal Court, 2005); the last and most recent is Called to Account (Tricycle, 2007). We will preface our descriptions of each with a brief introduction to the notion of verbatim theatre.

Verbatim theatre, as the name suggests, involves the re-creation on stage of the recorded speech of real individuals. Some verbatim work focuses on the dramatic possibilities inherent in the vagaries of oral discourse, drawing attention to the ticks and idiosyncrasies of individual speech as a means of defamiliarising human

31 Boyd White, 1985 (n 24) 36.

32 See, for example, A MacIntyre, After Virtue: A Study in Moral Theory, (2nd edn Duckworth, London 1985). 
communication. ${ }^{33}$ More often, however, verbatim theatre has a political agenda, drawing on the speech of individuals involved in particular situations in order to give a public platform to their experience of matters of concern to society in general. This strand of verbatim drama has evolved from the tribunal plays staged by London's Tricycle Theatre since 1994, which have drawn on official records made of public, usually legal, hearings to recreate the event in edited form for a wider public. ${ }^{34}$ In recent years the Tricycle has expanded its remit to create theatrical tribunals in instances where actual legal process has seemed to the practitioners conspicuous by its absence, while other theatres have deployed personal testimony recorded in a non-legal context to make interventions which seek to have an impact on a political and a legal level.

Verbatim theatre is seen as an effective means of addressing political situations in general and human rights issues in particular because it offers a specific kind of theatrical experience. As Richard Norton-Taylor, one of the pioneers of the form, has stated, 'there is something extraordinary about real people saying real things about extraordinarily important events. ${ }^{35}$ Central to the effect of verbatim theatre is the fact that these real people and real statements are presented in a dramatic context where fiction is the usual mode, so that audiences are accustomed to respond on an imaginative rather than practical level. A different kind of attention, therefore, may be paid to human rights issues when they are articulated here than when they are raised in more familiar contexts such as broadcast and print journalism. As Chris Megson has written: ${ }^{36}$

At their best [verbatim plays] enable their audiences to undertake a collective act of bearing witness. They replay political events or spoken testimony in order to retrieve a sense of the complexity of issues that have been too easily turned into digestible headlines.

The three plays that serve as our examples, then, are all intended to foster in their audiences a new understanding, emotional as well as intellectual, of the situations they dramatise and the experiences they articulate.

33 The work of fringe company Non-Fiction Theatre, for instance, has centred around the conceit of actors recreating the voices of members of the public, interviews with whom they are simultaneously listening to on personal minidisc players. Their shows Sex 1: Death 2 (2001) and We Haven't Told a Porky Pie Yet (2002), directed by Mark Wing-Davey, met with some success in London and Edinburgh.

34 The chief instigators of the tribunal plays have been the Tricycle's Artistic Director Nicholas Kent and the writer and journalist Richard Norton-Taylor. Their first tribunal production was Half the Picture (1994), which dramatised the Scott Arms to Iraq inquiry; this was followed by Nuremberg (1996); Srebrenica (1996); The Colour of Justice (1999), which recreated the inquiry into the murder of black teenager Stephen Lawrence; Justifying War (2003), based on the Hutton Inquiry into the death of weapons inspector David Kelly; and Bloody Sunday (2005). Guantánamo (2004) and Called to Account (2007) represent variations on the tribunal model.

35 Speaking at the Central School of Speech and Drama symposium Verbatim Practices in Contemporary Theatre on 14 July 2006.

36 C Megson, ““This is all theatre”: Iraq Centre Stage’ (Fall 2005) 15 Contemporary Theatre Review 369, 371. 
The first, Guantánamo: 'Honor Bound to Defend Freedom', takes as its subject the now notorious internment camp, and the script draws primarily on interviews with exdetainees and their relatives, as well as on public statements made by officials including the then US Secretary of Defence Donald Rumsfeld. The audience hear from a range of legal perspectives, and indeed the play's opening speech is taken from Lord Steyn's 2003 FA Mann lecture in which he described the camp as 'a legal black hole.. ${ }^{37}$ The picture built up is of considerable injustice, and the play has been described as an 'unashamedly ... partisan work' offering a counter to mainstream pro-US reporting in that country. ${ }^{38}$ Appropriately, given this function, the play has reached an unusually wide audience in a number of countries. ${ }^{39}$

Our second example, also drawing on verbatim testimony and focusing attention on international injustice, is My Name is Rachel Corrie. Performed by a single actress who speaks directly to the audience, the script is made up of the writings-taken from journals, letters and emails — of a young woman from the US who travelled to Palestine, worked to highlight the plight of the occupied people, and died standing between a bulldozer and a Palestinian home in March 2003. Corrie's story is emotive, but her eloquence on behalf of the Palestinian people ensures that the play is also rich in intelligent political argument. Following its 2005 Royal Court premiere, the performance history of My Name is Rachel Corrie is both extensive and controversial. When a New York run of the production scheduled for Spring 2006 was cancelled at short notice following concerns expressed by members of the local Jewish community, the play instead enjoyed a further London run in the West End and a sojourn at the Edinburgh Fringe Festival. In October 2006, the production finally opened off-Broadway at the Minetta Lane Theater where it played until December. ${ }^{40}$

37 V Brittain and G Slovo, Guantánamo: 'Honor Bound to Defend Freedom' (Oberon Books, London 2004) 5.

38 This comment was made during a conference presentation by Dr Valerie Lucas, Guantanamo: Honor Bound to Defend Freedom, PSi \#12: Performing Rights, Queen Mary, University of London, 14-18 June 2006.

39 The first performance at the Tricycle took place on 20 May 2004, and the production subsequently ran at the New Ambassador's Theatre from 16 June to 4 September. A parallel production opened in New York at 45 Bleecker on 19 August of the same year, transferring to the Culture Project, Greenwich Village and closing on 19 December. For two performances in October, the part of Lord Steyn was played by Archbishop Desmond Tutu (see Simon Hattenstone, 'My first night in Guantánamo' The Guardian 6 October 2004). Performances in San Francisco, Washington, Florence and Pakistan and a programme of public readings by school and community groups as well as theatre companies in the US were attested to by Gillian Slovo speaking at the Central School of Speech and Drama symposium Verbatim Practices in Contemporary Theatre on 13 July 2006. A production in Chicago ran between 11 February and 26 March 2006 at Timeline Theatre Company, on which see www.timelinetheatre.com/guantanamo/index.htm (accessed 17 July 2008).

40 The production enjoyed two sold-out runs at the Royal Court, first at the smaller Theatre Upstairs and then in the main house. The play's run at the Playhouse Theatre, between March and May of 2006, also sold out, before the production moved north for 24 further performances at the Pleasance Grand, Edinburgh. At the Minetta Lane Theatre, which seats 407, Rachel Corrie was initially programmed for 54 performances in October and November 2006, and the run was then extended to 17 December 2006. For more on the initial withdrawal of the New York production see K Viner, 'Surely Americans will not put up with this censorship' 
Our final example is the Tricycle's Called to Account (2007), which sought to assess whether a legal case could or should be mounted against Tony Blair for the crime of aggression with respect to Britain's part in the 2003 invasion of Iraq; here the focus was not on those suffering but on the political process that led to that suffering. As with Guantánamo, the authors of this play were obliged to gather testimony themselves in the absence of a formally constituted legal hearing (in fact, it would not be possible to hold such a hearing at present because the International Criminal Court does not as yet exercise jurisdiction over the crime of aggression). Called to Account breaks new ground, however, by explicitly structuring the presentation of that testimony in a quasi-legal form, with actors playing real lawyers who had been appointed by the theatre to present cases for the prosecution and the defence. The central issue that emerged from the play was whether the advice on the legality of the assault provided by the Attorney General was given in good faith or whether its favourable verdict had been dictated by a political imperative. The performance concluded with a summing up from each side, leaving members of the audience-placed throughout in the role of jurors- to reach an overall conclusion. Public interest in the issues dramatised was indicated by the fact that the initial four-week run was extended to seven, 'owing to unprecedented public demand'.41

Although all are variations on the model of verbatim theatre, each of the three plays provides an audience with a particular and distinct kind of theatrical experience. Guantánamo juxtaposes testimony given in private interviews with dialogue taken from speeches and press conferences to expose the private anguish caused by public policy. The result is epic in scale, in that the audience are granted an apparently omniscient view of a range of situations in a range of locations over a period of years. By contrast, Rachel Corrie encourages sustained engagement with the words of a single individual and with her journey through life. As mixed emotions about a precocious naïve give way to admiration and compassion for a committed activist, the play acquires a cumulative and powerful emotional charge. Called to Account is different again, a more forensic exercise in which punctilious mirroring of legal process serves to emphasise and implicitly decry the absence of actual legal proceedings. Here, though there are moments of levity and appeals to the emotions, cool reason is the dominant mode of spectatorship. Underlying these differences of approach, however, are similar if not identical intentions: to inform, to inspire compassion and to raise consciousness.

The Guardian (London) 1 March 2006, http://arts.guardian.co.uk/comment/story/0,,1720592,00.html (accessed 17 July 2008); and A Barnes, 'Too hot for Broadway' The Independent (London) 14 May 2006, www.independent.co.uk/arts-entertainment/theatre/news/too-hot-for-broadway-478169.html (accessed 17 July 2008).

41 'Called to Account extends booking period', indieLONDON, www.indielondon.co.uk/TheatreReview/called-to-account-tricycle-theatre (accessed 17 July 2008). The play ran from 19 April to 9 June, as indicated on the website of the Tricycle Theatre at www.tricycle.co.uk/htmlnew/whatson/show.php3?id=106 (accessed 6 February 2008). 
The first of these intentions is probably the most obvious: to disseminate facts and thus to enable informed debate. In Called to Account, for example, the audience hears testimony from several senior political and military figures concerning the background to the invasion of Iraq in 2003. Sections from the text of the Attorney General's advice to the Prime Minister (dated 7 March 2003) which was equivocal about the potential legality of any use of force are displayed for the audience, who are thus able to analyse it in some depth and address the apparent discrepancies between this statement and the far less equivocal statement made by the Attorney General in the House of Lords ten days later. Presenting evidence in an imaginary criminal trial encourages the audience to weigh its strengths and weaknesses and to reach a conclusion (or verdict) on the issues before it; by contrast, an actual judgment from the International Criminal Court addressing the same issue could only be received as determinative of the legal question(s) at issue, closing down rather than stimulating discussion. Similarly, imparting information about the lives of the detainees and their families in Guantánamo equips audiences to consider the morality of the men's detention, allowing them to engage with, and perhaps even resolve through judgement, the issues under discussion.

These plays are also designed to inspire compassion. Looked at broadly, all three plays draw the attention of their audiences to human rights failures: Guantánamo presents a case for the detainees it represents; Rachel Corrie points to the injustice of one woman's death, but also the wider injustice of an illegal occupation; and Called to Account questions whether a devastating invasion was launched with moral or legal justification. Through drama, the situation is made easier to grasp on an empathetic, human level. To see, for instance, the detainees in Guantánamo in their tiny cells, on stage as the audience enter the space and throughout the performance, reading, eating and praying, is to get a much clearer sense of what it would be like to be indefinitely confined in this cramped and sterile space. This understanding is broadened when we hear from the detainees' families about the wider suffering and anxieties that the detentions have generated. In Rachel Corrie, when the narrator describes an explosion that breaks all the windows in the house while she is 'being served tea and playing with the two small babies', ${ }^{42}$ the audience is allowed a glimpse of the domestic reality of life in Palestine, a reality that is otherwise difficult to imagine. By means such as these, the plays are clearly intended to arouse compassion, a compassion which, as in Gearty's model, contains the seeds of action.

A third aspiration informing these plays is to raise consciousness by challenging mainstream accounts and giving voice to the point of view of the dispossessed. In Called to Account official versions of events are interrogated and opened for challenge. For example, Claire Short says of the Prime Minister under whom she served, 'he doesn't see it as lies, but I'm afraid it is lies', ${ }^{43}$ vividly conveying a sense of the slippery, subjective

42 A Rickman and K Viner (eds), My Name is Rachel Corrie (Nick Hern, London 2005) 49.

43 R Norton-Taylor (ed), Called to Account (Oberon, London 2007) 39. 
politics at work at every stage of the process that led to war. At the outset of the play, we hear from an Iraqi Kurd relating the gross human rights abuses experienced by the Iraqi people under Saddam Hussein's regime. In Rachel Corrie and Guantánamo, the voices of human rights victims take centre stage and the stories unfold around the narratives of those who would, in more formal arenas, too often be silenced. Through this attempt to connect human rights with the language of suffering, theatre is here deployed as a means of laying bare the narratives of the powerful.

If these plays issue a challenge to a dominant discourse to which legal language and practice is central, we might expect it to follow that they are both explicitly and implicitly critical of law as a means of furthering the causes they espouse. After all, what is presented in each of these plays is the failure of formal legal remedies to address gross human rights violation and, where human rights laws are referred to, it is in the context of their neglect. The effect must be to remind us that the privileged position that formal laws occupy within the dominant discourse should not blind us to their limitations as a means of securing human rights and redressing human rights violations, and to signal that legal positivism is a poor means of protecting individuals against excessive state power. However, although the plays certainly draw attention to some of the shortcomings of the legal approach to the alleviation of suffering, they do not suggest that the law should be despaired of altogether. The prevalence of legal language and the reliance upon legal structure and principle that are evident throughout each indicate the usefulness of law within human rights discourse on a practical, political level, while the ways in which the legal interacts with the dramatic show that there can be a productive, collaborative relationship between the two.

On a straightforward level, Guantánamo, Rachel Corrie and Called to Account confirm the authoritative position of law in human rights discourse, supporting their claims of injustice by asserting a concomitant illegality and investing authority in representatives of the law. This is particularly apparent in Guantánamo and Called to Account in which lawyers are represented on stage, making an articulate case for the detainees in the former and carefully_indeed, judiciously_sifting the evidence in the latter. In Guantánamo, the customary respect which is shown to the law and its representatives is uncritically reflected, and even encouraged, in order to strengthen the case being made; indeed, one reviewer favourably compared the rhetorical effectiveness of Gareth Peirce as played by Jan Chappell to that of Gareth Peirce herself, taking part in a post-show discussion. ${ }^{44}$ The

44 Fellow cast member David Annen, speaking at the Central School of Speech and Drama symposium Verbatim Practices in Contemporary Theatre on 13 July 2006, explained that Chappell had given the character the charisma and authority that the audience expected, 'transform [ing her] into someone whose presence could fill a large room'. At the same event Gillian Slovo described a special performance of Guantánamo at the Houses of Parliament in which Stafford Smith played himself and was good-humouredly heckled during the curtain call ('That's what you get when you don't hire Equity', an audience member called out, referring to the British actors' union). 
final speech in the play is delivered by Lord Steyn, thus giving the last word to an eminent lawyer, and lengthy extracts from the same speech were reproduced in the programme, as were sections of the Geneva Conventions. In the pseudo-legal process enacted by Called to Account it is members of the audience who are designated as arbiters, the lawyers' role being primarily to elicit information from witnesses. However, here too the event both begins and concludes with speeches from lawyers, and the play's overall format strongly encourages audience members to make their decisions on the basis of legal principle and to formulate and express them in legal terms.

Moreover, the plays repeatedly show non-lawyers appealing to legal practice and principle in their pursuit of justice. In Guantánamo, detainee Jamal Al-Harith protests that 'the Americans said, "There's no law here, it does not apply", ${ }^{5}$ while a father's plea on behalf of his son is couched in these terms: 'I'm not asking mercy from anybody. I am asking justice ... Justice in process ... Human rights justice. ${ }^{46}$ In Rachel Corrie, the titular protagonist is shown using legal arguments, among others, to condemn Israeli military action against the Palestinians: ${ }^{47}$

When someone says that any act of Palestinian violence justifies Israel's actions not only do I question that logic in light of international law and the right of people to legitimate armed struggle in defence of their land and their families; not only do I question that logic in light of the fourth Geneva Convention which prohibits collective punishment, prohibits the transfer of an occupying country's population into an occupied area, prohibits the expropriation of water resources and the destruction of civilian infrastructure such as farms ... I also question that logic on the basis of common sense.

Not only do such references show that the victims and campaigners represented in these plays believe law to be a useful tool in their quest for justice, but the fact that the claims of the dispossessed are framed in legal terms gives them a particular resonance and authority, recalling Patricia Williams' point that the language of legal rights can be empowering in itself. More broadly, the quasi-legal structure of Guantánamo and especially Called to Account are manifestations of an implicit faith in law as the mechanism through which practical redress must ultimately be effected. For lawyers, too used to communicating in a rarefied language that serves to deflect, rather than attract, wider scrutiny of legal language and practices, there is something inspiring in theatre's capacity to inform and engage people in discourse that touches on legal matters. It might even be argued that it is the plays' references and appeals to the law that make them specifically political entities, as opposed to existential explorations of human suffering or folly directed towards no practical purpose.

\footnotetext{
45 Brittain and Slovo (n 37) 45.

46 Ibid, 60.

47 Rickman and Viner (n 42) 48.
} 
These plays, then, are critical of law insofar as its enforcement cannot always be relied upon where it conflicts with the interests of powerful States, but at a deeper level supportive of the principle that it is through the observance of the rule of law that justice may be attained. This is not simply to say, however, that they act as effective advertisements for the law as understood as a self-sufficient and wholly effective means of guaranteeing justice. Rather they demonstrate that law's utility does not end in the courtroom, and encourage us to view law not as a discrete entity functioning autonomously but as a site of discourse generating ideas, language and principles which are then available for wider utilisation. Moreover, by taking what has been said and done in one context and placing it before the public in another, these plays can give amplified expression to voices normally sidelined by or excluded from the dominant discourse, engaging audiences on an empathetic level and inspiring their compassion. In this way, they encourage us to re-envision the end of the formal legal process as the starting point of a further process, one which goes beyond law but from which law is by no means excluded, and one which can release the radically transformative potential of human rights.

\section{THE EFFICACY OF THEATRE AS A MEANS OF ADVANCING HUMAN RIGHTS}

The three plays examined here are responses to injustice, and no one could deny the honourable intentions of their authors; there are, however, good reasons to doubt whether performances of these plays can have had any kind of practical impact on the problems being addressed. One response to the question of how effectual a piece of theatre can be is that there is value in asserting a truth, or a position, even if that assertion leads to no tangible change. Clive Barker, writing at a time when political theatre was very much on the back foot following the fall of the Berlin Wall, wrote: ${ }^{8}$

If times become hard and repressive ... there is value in bearing witness. Whatever is happening in Britain and in the rest of Europe, people are starving and oppressed, and the dispossessed are being abused. In this world the theatre still has a role. The minimal role in protest is to stand up and be counted.

Here Barker asserts theatre's value as a means of expression, something few would question, but he also indicates that expressing a viewpoint is political theatre's 'minimal' function, the least it can do. As Bertolt Brecht said of his own practice, 'I wanted to take

48 C Barker, 'Alternative Theatre/Political Theatre' in G Holderness (ed), The Politics of Theatre and Drama, Insights (Macmillan, Basingstoke 1992) 38. 
the principle that it was not just a matter of interpreting the world but of changing it, and apply that to the theatre. 49

Brecht remains the practitioner who has most fully articulated the ambitious intentions behind political or campaigning theatre. He believed that theatre should inform, should 'put living reality in the hands of living people in such a way that it can be mastered'; $; 0$ he believed that it should agitate, should arouse 'indignation at human conditions' $;{ }^{31}$ and he believed that it should empower, encouraging active consideration of the topics highlighted so that 'the spectator, instead of being enabled to have an experience, is forced as it were to cast his vote. ${ }^{52}$ In this way, he wrote, 'theatre, art and literature ... [can] form the "ideological superstructure" for a solid, practical rearrangement of our age's way of life. ${ }^{53}$ Brecht's avowedly Marxist theatre called for fundamental social change whereas our three plays focus on particular issues; nonetheless the purpose of Guantánamo, Rachel Corrie and Called to Account is to make strong and effective societal interventions in the tradition of political theatre as defined by Brecht. We now consider how far, and in what ways, this objective is likely to have been achieved.

The question of how theatre affects its audiences, and thus of to what degree its authors can hope to effect wider change, has been widely considered. Baz Kershaw's 1992 study The Politics of Performance seeks to assess how far thirty years of radical community theatre were successful in their aim of changing society. In this context he considers in some detail the efficacy of performance, first defining this term: ${ }^{54}$

... by efficacy I mean the potential that theatre may have to make the immediate effects of performance influence, however minutely, the general historical evolution of wider social and political realities.

However, as Kershaw goes on to acknowledge, 'the longer-term effects-ideological or otherwise - that a performance actually might have on its audience ... are notoriously difficult to determine, ${ }^{55}$ a problem that emanates not from the nature of theatre itself but from its relationship with 'the wider social order, in all its discursive and institutional complexity. ${ }^{56}$ It is one thing to conceptualise a public sphere and to reason that cultural products affect public opinion which must, in turn, affect political policy; it is another to identify concrete examples. Kershaw's solution to this apparently intractable problem is to examine the potential, rather than the actual efficacy of the radical performances he

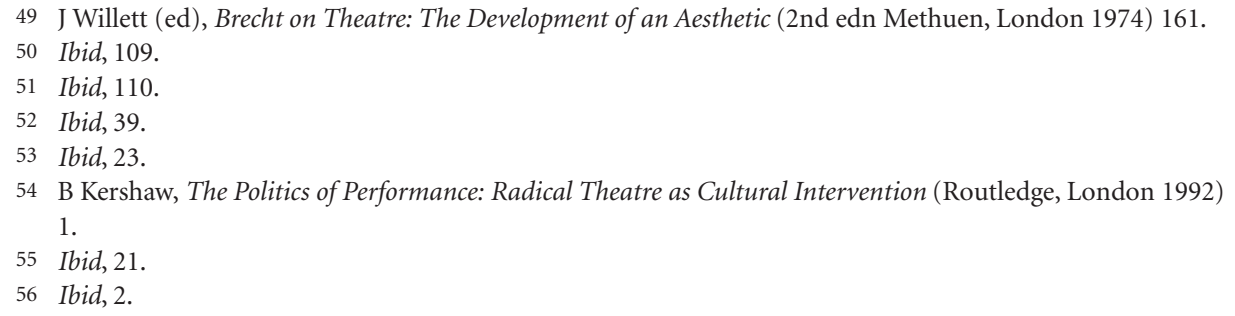


describes. Guantánamo, Rachel Corrie and Called to Account are theatre of a much more mainstream kind, though there is a formal innovation to consider in terms of their use of verbatim material. Our approach here will be to compare the general efficacy of theatre to that of other, more mainstream modes of communication, and then to consider more particularly the likely efficacy of verbatim theatre as against that of other, more fully fictive modes of performance.

One obvious consideration is the scale on which these plays can have had their effect. It has to be acknowledged that, in comparison to other forms such as film, television or even the novel, the theatre is a minority concern, speaking only, as Richard Schechner has noted, to 'the relatively few who pay attention' ${ }^{25}$. By the standards of theatre, and nonmusical theatre in particular, Guantánamo, Rachel Corrie and Called to Account have been widely viewed but, by the standards of mass culture media, the numbers involved are tiny. Moreover, many of those attending these plays are likely already to have been in agreement with their central assertions, further lessening the likelihood that minds can have been changed on a large scale. Hopes for the practical effectiveness of these plays, therefore, would seem to rest not on their reaching a mass audience but on their having a powerful effect on a relatively small number of people. Before we consider the kind of effect they might have had, though, it is worth noting that the plays were produced at theatres with a high degree of cultural prestige, attracting audiences largely from the educated, professional classes, and thereby assisting a group of well-informed and critically engaged citizens to contribute to debate in the public sphere. Seen from this angle, theatre's often criticised status as an elitist art form can be seen to have an upside.

Moreover, in formal terms, and notwithstanding their much wider reach, theatre has been favourably compared to television news and print journalism as a means of addressing human rights issues. The problem ascribed to conventional mass culture representations is twofold, relating both to our ability to grasp the information presented intellectually and to our capacity to engage with it on a human, emotional level. Faced with the daily horror of the news, Gareth Peirce suggests in Guantánamo, 'we read, we watch, we hear about atrocities ... but ... we don't have the capacity to take it in and react to it in the way we should as human beings. ${ }^{58}$ Similarly, writing in August 2004, Kate Kellaway of the Observer contrasted the fragmented nature of much television news with the sustained focus that may be achieved in the theatre, writing that 'it is a remarkable moment for political theatre ... people want from [it] a clarity they are not getting from politicians. ${ }^{59}$ Finally, Rachel Corrie's parents have suggested that ${ }^{60}$

57 R Schechner, 'The Big Issues and the Happy Few' (2004) 48(2) The Drama Review 7.

58 Brittain and Slovo (n 37) 52.

59 K Kellaway, 'Theatre of War' The Observer 29 August 2004.

60 Craig and Cindy Corrie, 'Play Reveals Many Dimensions of Rachel', website of the Rachel Corrie Foundation at http://rachelcorriefoundation.org/site/category/my-name-is-rachel-corrie/page/5 (accessed 17 July 2008). 
Theater can reach people in a different and deeper place than reading a news article or listening to a speech: there is an emotional aspect that for some people can be more long-lasting and motivating.

This emphasis on clarity and humanity reflects Brecht's aim that theatre should 'put living reality in the hands of living people in such a way that it can be mastered', making information not only available but graspable in both intellectual and emotional terms. This is a function which has arguably become more important at a time when we do not suffer so much from a lack of information but rather from a disorientating surfeit: a condition described by Jean Baudrillard as 'a completely new species of uncertainty, which results not from the lack of information but from information itself and even from an excess of information' ${ }^{61}$

If theatre can be seen to possess advantages over mass culture forms as a means of representing pressing situations with clarity and humanity, the claim of verbatim theatre is that it possesses greater authority than can conventional drama due to its exact and demonstrable relation to objective reality. It is of course true that no representation can ever be entirely accurate or wholly objective, but nonetheless the conscientious recreation of recorded speech makes verbatim theatre less inaccurate and less subjective than a purely fictive response to the same situation; the aim is that the situations dramatised are regarded as real. How the audience may be expected to receive a verbatim performance, however, is an interesting question, because it is central to the way in which audiences habitually attend to theatre that they understand the events they witness on stage not to be real.

Anthropologist Victor Turner makes connections between ritual and theatre, marking out the former as creating for tribal societies a liminal space situated at the threshold between one state and another and the latter (the product of more complex, industrial societies) carrying forward some of the same properties to give audiences an experience which is 'liminoid'. Turner characterises leisure time as 'a betwixt-and-between, a neitherthis-nor-that domain between two spells of work' and entertainment such as theatre as 'all play and choice'.62 As Kershaw writes, this means that the events of a play are accepted as 'both real and not real'; and, precisely because spectators are permitted to 'treat the performance as of no consequence', it may act as 'a kind of ideological experiment', in the course of which the spectator may in fact decide that 'the performance is of central importance to his or her ideology'. ${ }^{63}$ It is in such ideological adjustments, Kershaw believes, undertaken collectively by members of a given audience or audiences, that performance efficacy is ultimately to be located.

61 J Baudrillard, Selected Writings, Mark Poster ed (Polity, Cambridge 1988) 210.

62 V Turner, From Ritual to Theatre: The Human Seriousness of Play, Performance Studies Series 1 (PAJ Publications, New York 1982) 40-43.

63 Kershaw (n 54) 24-29. 
It may be that this is at the root of the perceived advantages of theatre over other forms of communication cited by Peirce, Kellaway and the Corries. Freed from the obligation to consider what is witnessed as real and consequential, theatre audiences may be readier to engage imaginatively with what they see, and thus to respond at a deeper level, their habitual defences dropped. However, the particular aims and nature of verbatim theatre complicate the model. In Guantánamo, Rachel Corrie and Called to Account, as with all examples of the form, the balance between 'both real and not real' is slightly different. Here the choice is not whether to accept a given piece of fiction as relevant or otherwise, for it is not fiction that is being presented and the relevance of the action is insisted upon by the producers and performers. Rather, the choices that an audience member may face when presented with purportedly factual situations in a context habitually associated with the fictive are whether to trust or not to trust, and whether to be convinced or otherwise. However great the integrity of the practitioner, these choices will remain, though of course the more accurate the play is perceived to be, the more likely it is to be trusted and to convince.

A further distinction that might be of assistance here is Elaine Scarry's between 'the made-up and the made-real'. Acknowledging a contemporary enthusiasm for highlighting the constructed nature of phenomena more usually taken as given (among the examples Scarry cites are quarks, wildernesses, childhood and the law), she argues that these remain distinct from the overtly fictional, overtly constructed phenomenon of art. While they share with art their constructed nature, in the case of a phenomenon of the former kind ${ }^{64}$

... the initial work of invention was compounded by an additional process through which reality was conferred on it or discovered in it; and the essence of this second stage lay in the making invisible of the traces of its having been created in the first place.

It is interesting to surmise what Scarry might make of verbatim theatre. She might well argue that, for all the attempts at 'making real' that are represented by the practitioners' strivings for authenticity, plays such as Guantánamo remain constructed events and therefore, in her terms, 'made-up. This would be hard to refute. She might go on, however, to point out that this constructedness may be less overt than that of a conventional drama but is surely less covert than is that of a quark or the law; she might even suggest that, by virtue of its status as self-evidently constructed, verbatim theatre invites engagement with its subject matter in a context wherein reality is conceived of as shapeable and changeable rather than fixed and immutable. According to this line of thinking, the constructed nature of verbatim theatre implicitly draws attention to the constructed nature of, for

64 E Scarry, 'The Made-Up and the Made-Real' in M Garber, RL Walkowitz and PB Franklin (eds), Fieldwork: Sites in Literary and Cultural Studies (Routledge, London 1996) 217. One instance of the 'second stage' to which she refers might be the ratification of a proposed law, making it binding and therefore a fact to be negotiated. 
instance, the rationale for detaining those held at Guantánamo, the perception that the Palestinians are responsible for their own plight, and the Blair government's case for war. If this is so, then it is significant because, as Scarry asserts: 'Seeing that a phenomenon is constructed, our own access to the artifact increases, as does the chance to reshape it, if it is in need of reshaping: if, for example, it endangers other people. ${ }^{65}$ What evidence there is indicates that Guantánamo, Rachel Corrie and Called to Account elicited emotional responses from audiences. Lyn Gardner, reviewing My Name is Rachel Corrie for the Guardian, urged her readers to see the production: ${ }^{66}$

Go, and take your teenagers with you ... because just occasionally you see a show in the theatre and hear a voice that, like Rachel's, vibrates with a passion and idealism, and that teaches us all how to live.

When Guantánamo opened in New York, the journalist Gary Younge captured some reactions from members of the audience. I I felt confused as to whether I should appreciate it as art or as real life, because it was really both,' said one, indicating that the play had obliged him to renegotiate his habitual responses to theatre. Another commented, 'I knew the stories cold ... but I was still completely moved,' while a third said, 'I was expecting to have an intellectual response. But it was very emotional. I cried.' 'This is the kind of play that should be seen by 30 million Americans,' was the conclusion of Richard Levy; 'It could really make a difference and change their understanding. ${ }^{67}$ Even the comparatively arid Called to Account provoked 'gasps and then tears'. 68

The basis of claims for the practical efficacy of theatre is that a performance has the potential to alter the wider socio-political situation by affecting the thoughts and, perhaps more importantly, the feelings of those who witness it, thereby influencing their future action: as Kershaw writes, 'the immediate effects of performance' must 'influence, however minutely, the general historical evolution of wider social and political realities. ${ }^{69}$ The immediate effect of these plays was, the responses cited suggest, to arouse compassion, but just as significant is the relationship with reality that the performances were seen to have. Theatre, and verbatim theatre in particular, facilitates an imaginative and empathetic reaction to real situations with which we may already be familiar but which we are unlikely to have fully apprehended. Though the relationship between the real and the not real in a verbatim performance is a complex one, the effect seems to be that the external

65 Ibid, 216.

66 L Gardner, 'My Name is Rachel Corrie' The Guardian (London) 1 April 2006, http://arts.guardian.co.uk/ critic/feature/0,,1744421,00.html (accessed 17 July 2008).

67 G Younge, 'Fortress New York takes post-9/11 play to its heart' The Guardian (London) 28 August 2004, www.guardian.co.uk/world/2004/aug/28/arts.usa (accessed 17 July 2008).

68 L Carim, 'Review: “Called to Account”', 2 May 2007, UCL website at www.ucl.ac.uk/news/news-articles/0705/ 07050203 (accessed 17 July 2008).

69 Kershaw (n 54) 1. 
reality to which the performance relates can be more fully recognised by audience members as a result of that performance. Recognition need not necessarily lead to behavioural change, but it seems unduly pessimistic to suggest that nothing audience members learned or felt while watching Guantánamo, Rachel Corrie and Called to Account led to alterations in their views and, thereby, to 'the general historical evolution of wider social and political realities'.

\section{CONCLUSION}

Human rights exist to provide a language through which to respond to injustice and inhumanity; as Conor Gearty has argued, the term 'human rights' signifies an imaginative understanding of suffering that insists on action. Some critics have despaired of human rights on the basis that their expression through legal discourse is inadequate to articulate the human suffering that they are intended to alleviate. We have argued, however, that the equation of human rights with formal human rights laws existing in isolation is neither realistic nor helpful, and that the simultaneous articulation of human rights within other cultural forms can make more fully evident the connection between rights and suffering. What makes plays such as Guantánamo, Rachel Corrie and Called to Account effective is their capacity to arouse a compassionate response to the suffering dramatised that acts as a spur to action. Precisely because theatre is a medium that invites an imaginative rather than a practical response, the dramatic representation of human suffering allows for a sustained empathetic engagement with the issues explored and creates, therefore, a greater likelihood that audience members will contribute to debate within the public sphere and, indeed, will act upon their experience of the drama. It is by making the connection between human rights and human suffering that has been seen to be lacking that these plays make their valuable contribution to the discourse of human rights. 
